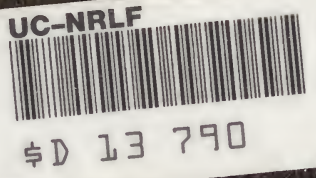



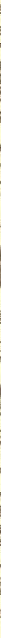

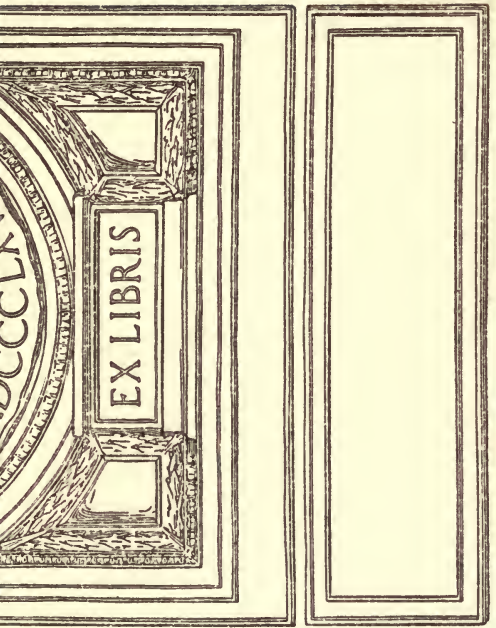







$$
\begin{aligned}
& \text {, , , } \\
& 3 \rightarrow, j \\
& \text {, , , , }
\end{aligned}
$$

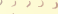

$$
\begin{aligned}
& \text {, , , } \\
& \text { 2, , , } \\
& \text {, , , , , , , } \\
& \int^{3} \int^{3}
\end{aligned}
$$

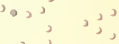

$$
\begin{aligned}
& , 3,3 \\
& 3,30 \\
& 3 \\
& \text { כ } \\
& \text { 25030 } \\
& \rightarrow \\
& 3_{3}^{3} \\
& 3^{2} 0^{2} \\
& \int_{3}^{3} a^{3} \\
& 323 \\
& \text { I } 2 \\
& >3 \\
& 203 \\
& a_{3}^{3} 3 \\
& 303
\end{aligned}
$$




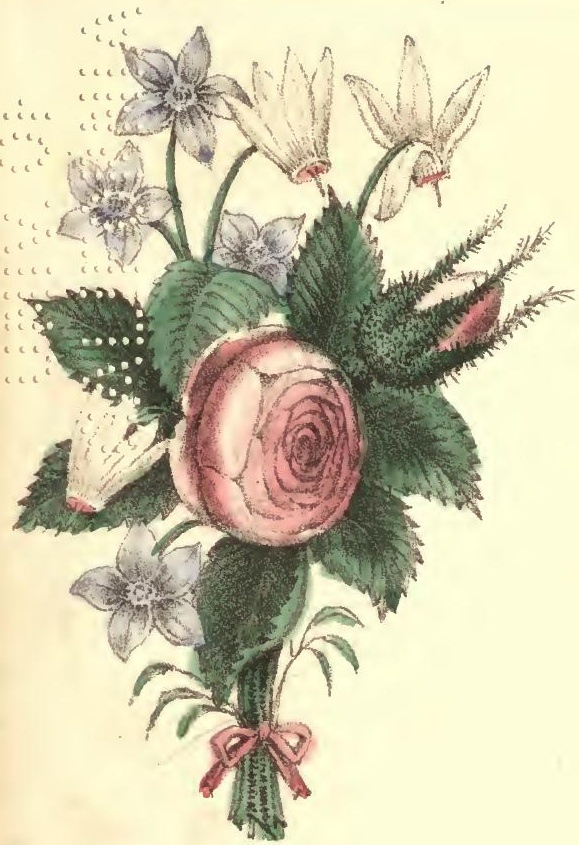




\section{THE}

\section{VOICE OF FLOWERS.}

\section{MRS. L. H. SIGOURNEY.}

"Bring flowers-bright flowers."

Mrs. Hemans.

FOURTH EDITION.

HAR TFORD:

H. S. PARSONS AND CO. 

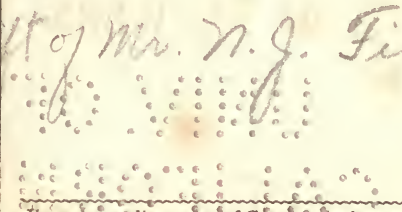

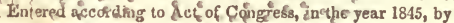

\section{H. S. PAR SONS \& CO.,}

In the Clerk's Office of the District Court of Connecticut.

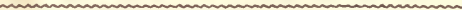

Stereotyped by

R I CHARD H. HOB B S,

Hartford, Conn. 


\section{INDEX.}

Page.

Flowers, . . . . . . . . . . . 5 The Winter Hyacinth, . . . . . . 7 He told his love in flowers, . . . . . . 9 The Disobedient Pansy, . . . . . . 12 The Lobelia Cardinalis, . . . . . . . 14 The White Lily, . • . . . . . . 17 Flora's Party, . . . . . . . 18 The Tulip and Eglantine, . . . . . . 29 The Blossom and the Beautiful, . . . . 30 The Snow-Drop, . . . . . . . . 32 The Cactus Speciosissimus, . . . . . . 33 The Dahlia and Verbena, . . . . . 35 The Desert Flower, . . . . . . . . . 37 Minerva's Prize, . . . . . . . . . . 39 King Frost and the Garden Beauties, . . . 42 Transplanted Flowers, . . . . . . 45 Wild Flowers gathered for a Sick Friend, . . 47 Gossip with a Spring Bouquet, . . . . . 48 The Hollyhock and her Visitor, . . . . 53 The Evening Primrose, . . . . . . . 56 The Constant Friends, . . . . . . 57 The Tears of April, . . . . . . . 59 Planting Geranium and Box on the Grave of an Aged Friend, 
iv

INDEX.

Page.

Forgotten Flowers. To a Bride, . . . . 64 Circle of Friends compared to Flowers, . . 66 Blossoms falling from Fruit-trees, . . . . 74 The Willow, Poppy, and Violet, . . . . 76 The Early Frost, . . . . . . . . . 79 The Stranger's Flower, . . . . . . . 85 The Lily's Whisper, . . . . . . . 87 Planting Flowers on the Grave of Parents, . . 89 Alpine Flowers, . . . . . . . . 92 The Rose-Geranium, companion of a voyage, . 94 The Emigrant Daisy, . . . . . . 95 The Travelled Flower, . . . . . . . 97 Spring Blossoms to the Mourner, . . . . 101 The Hare-Bell, . . . . . . . . 103 Evening Flowers, . . . . . . . . 104 The Garden and the Rain, . . . . . 106 Changes during Sickness, . . . . . 110 Misletoe at the Tomb of Washington, . . 113 Ministry of Flowers, . . . . . . . 115 The Winter Bouquet, . . . . . . . 119 Farewell to Flowers, . . . . . . . 121 Glossary, . . . . . . . . 125 


\section{THE VOICE OF FLOWERS.}

\section{F L O WER S.}

SweET playmates of life's earliest hours ! They ne'er upbraid the child, Who, in the wantonness of mirth,

Uproots them on the wild; And when the botanist, his shaft, With cruel skill, doth ply, Reproachless 'neath the fatal wound, Martyrs to science die.

Wreathed brightly mid the locks of youth, They come to beauty's aid, And in this ministry of love

All unreluctant fade ;

To grace the bridal and the feast,

From sun and shower, they bring Such robes of glorious tint, as sham'd Judea's gorgeous king. 
-Anú when the faller meel tre scorn

Of man's disdainful eye,

They smile amid his path of thorn

With sweet and pitying sigh;

And to the brow of guilt and care,

The heart by anguish riven,

Still point, with angel-finger, where

The sinner is forgiven.

They shrink not in our ghastly shroud Their sad abode to take, And keep their vigil o'er the tomb,

When all beside forsake;

Down in their own dark sleep of death

They sink at wintry hour,

But in new glory rise to show

The soul's immortal dower.

Oh! sharers in our time of joy,

And weepers in our woe,

We bless ye,-children of the sky,

That by the wayside grow;

That to the cottage eaves go up,

Or wreathe the courtly hall,

Still, like the Power who call'd ye forth,

Dispensing love to all. 


\section{THE WINTER HYACINTH.}

How beautiful thou art, my winter flower! Day after day thy mesh of slender roots, That mid the water wrought their busy way, I 've watch'd intently through the chrystal vase That deck'd my maintel-piece.

Then, bursting forth,

Came leaves, and swelling buds, and floral bells, Replete with fragrance: while thy graceful form,

Fair Hyacinth, attracted every eye, And many a phrase of admiration woke, As from a lover's lip;--while unto me Thou wert as a companion, skill'd to smile All loneliness away.

But now-alas !

I mark the plague-spot stealing o'er thy brow, And know that thou must die.

$$
\text { In thy brief space, }
$$

Say-did thine inmost soul remember Him Of whom thy rare and pencill'd beauty spake So tenderly to us? And was thy breath A pure and sweet ascription to His praise? We trust it was ; for those who teach of heaven Should have its spirit too. 


\section{Yet, if like us,}

Poor erring ones, thou e'er didst leave undone What ' $t$ was the duty of thy life to do,

Haste, and repent thee! for the time is shortThe Spoiler cometh!

Drooping on the stem,

Methought it meekly folded its faint leaves For the last, voiceless prayer; while unto me A gush of fragrance was its benison.

At morn I came. No more its bosom glow'd ; A heavy sleep hung o'er its leaden eyes,And dews like funeral tears.

Oh, Friend! whose gift

Was the dark bulb that veil'd this glorious flower,

And unto whom, in gratitude, I turn'd, As its rich charms develop'd-come with me, And let us gather from its wither'd lips Some lingering sigh of wisdom.

\section{If we blend}

True love to God with every kindly deed Unto our fellow man, and steadfast stand At duty's post, still inly bow'd, as those Who feel the time is short-may we not wait For sleep's last angel, full- of placid trust, Like this sweet, folded flower? 
HE TOLD HIS LOVE IN FLOWERS.

\section{HE TOLD HIS LOVE IN FLOWERS.}

I'LL tell thee a story, friend,

Here, under this shady tree;

If thou 'lt keep it close in thy faithful breast,

I'll whisper the whole to thee

I had a lover once,

In my early, sunny hours;

A fair and fanciful youth was he,

And he told his love in flowers.

I remember its waking sigh ;-

We roam'd in a verdant spot,

And he cull'd for me a cluster bright

Of the purple "Forget me not."

But I was a giddy girl, So I toss'd it soon away,

Gathering the dandelion buds, And the wild-grape's gadding spray. 
He mark'd their blended hues

With sad, reproachful eye-

For one was the symbol of thoughtless mirth,

And one of coquetry.

Yet he would not be baffled thus-

So he brought for my chrystal vase The Rose-geranium's tender bloom, And the blushing Hawthorn's grace.

And a brilliant and fresh bouquet

Of the rich Moss-rose he bore, Whose eloquent buds with dew-drops pearl'd, Were full of the heart's deep lore.

I could not refuse the gift,

Though I knew the spell it wove ;But I gave him back a snow-white bud :

"Too young-too young to love."

Then he proffer'd a myrtle wreath, With damask roses fair,

And took the liberty-only think !

To bind it round my hair.

And he prest in my yielding hand

The Ererlasting Pea,

Whose questioning lip of perfume breath'd,

"Oh, say, wilt thou go with me?" 
HE TOLD HIS LOVE IN FLOWERS. II

Yet we were but children still,

And our love, tho' it seem'd so sweet, Was well express'd by the types it bore,

For it pass'd away as fleet.

Tho' he brought me the Laurel leaf,

That changes but to die,

And the Primrose pale, and Amaranth,

Yet what did it signify?

For over his vaunted love

Suspicion's mood had power-

So I put a French Marigold in his hat,

That gaudy and jealous flower.

But his rootless passion shrank,

Like Jonah's gourd, away,

'Till the cold Chrysanthemum best reveal'd The blight of its quick decay.

And he sail'd o'er the faithless sea To a brighter clime than ours :So it faded away, that fickle love,

Like its alphabet of flowers. 


\section{THE DISOBEDIENT PANST.}

A PANsy had many little ones. She talked much with them-daily instructing them, and set them a good example of sweet temper and humility.

She said often to them, "As soon as the great sun sinks away from you, and you feel the cool, fresh dews, compose yourself to rest. Look up smilingly, and breathe one sweet breath to Him who giveth the sun-beam, and the drops of dew.

When you have offered this, (the prayer of all good flowers,) fold your leaves, and bend your heads in sleep, for He will take care of you. The buds that thus early and piously go to rest, will flourish and be pleasing in His sight."

So her children obeyed her, all except one. This young pansy grew on rather a longer. stalk than the others; and it said, "I wonder why my mother is thus always lecturing us?"

"I think I know as much as she. I do not like to go so early to bed. I have heard that those who have genius are always brightest when it is late. I wish to see how the world looks at midnight."

So she omitted her prayers, and strained her 
eyes open as wide as she could. Her brothers and sisters were quietly sleeping around her, and she laughed at what she called their stupidity.

By and by she began to grow tired, when suddenly a huge black spider seized her in his claws. She cried out in terror, but no one was awake to hear her.

He held her so tight that she could scarcely breathe, and tears stood in her large, dark eyes. In the gray dawn he spun a web over her face, and fastened it to a neighboring shrub.

Her mother awoke early, and lamented over her; "Oh, my poor daughter, would that I could help you! Perhaps $\mathrm{He}$, to whom you forgot to pray, who is so good to all, may yet cause these chains to fall from you."

Bitterly did the young pansy deplore her disobedience. Her fright, and the spider's cords, with their tight lacing, had so compressed her heart and lungs, that she turned pale, and panted for breath.

When the noon-day sun beat fiercely upon her, she drooped and faded away-saying, with her last, faint sigh, "Oh! brothers and sisters, take warning by my sad fate. Never disobey our dear mother, for she is wiser than we." 


\section{THE LOBELIA CARDINALIS.}

"Cull me a flower," the Indian maid Unto her lover sigh'd-

"Such as thy noble spirit deems Fit for thy chosen bride.

"And I will wear it on my brow When from this home I part, And enter to thy forest bower, Thy true love in my heart."

With meek intent, and searching glance,

The chieftain pac'd the sodWho, with Acteon's haughty stride, Had erst that region trod.

Not now, to rouse the slumbering deer, Or scathe the eagle's throne, Thro' those secluded shades he roam'dHis heart was love's alone.

He cut the rich, wild rose, that still A lingering radiance castYet soon its falling petals told Its day of pride was past. 
He pluck'd the iris, deeply blue, The amaryllis, bright,

And stor'd their treasures through the day,

But cast them forth at night.

$\mathrm{He}$ bound the water-lily white,

\section{Amid her lustrous hair,}

But found her black and flashing eye

Requir'd a gem more rare.

At length, beside its mantling pool,

Majestic and serene,

He saw the proud Lobelia tower

In beauty, like a queen.

That eve, the maiden's ebon locks

Reveal'd its glowing power,

Amid the simple, nuptial rites

That grac'd the chieftain's bower.

But she, who, by that stately flower,

Her lover's preference knew,

Was doom'd, alas! in youthful bloom,

To share its frailty, too;

For ere again its scarlet spire

Rejoic'd in summer's eye,

She droop'd amid her forest home-

Her fount of life was dry. 
Then, as the ebbing palse declin'd,

Forth from her sacred nook,

With swimming eye, and trembling hand,

Her bridal wreath she took,

And bound its wither'd floral bells

Around her temples pale,

And faintly to her maidens spake-

For breath began to fail :-

"Should the last death-pang shake me sore, (For on they come with power,)

Press closer in my ice-cold hand

My husband's token-flower;

And rear the turf-mound broad and high To span my lonely grave,

That nought may sever from my locks The gift of love he gave-

So, when the dance of souls goes forth Athwart the starry plain,

He'll know me by his chosen flower, And I'll be his again." 
THE WHITE LILY.

\title{
THE WhITE LILY.
}

\author{
TO A YOUNG LADY.
}

WITH its pure and stainless breast, See the graceful Lily rise,

Bearing on its snowy vest

Pearly dew-drops from the skies.

Emblem of the youthful mind-

Fresh from Nature's pencil bright, And by Heaven's own smile refin'd For unfading realms of light.

Fair One-may thy life below, Like that peaceful flow'ret prove, And thy spirit's fragrance flow O'er the fervent heart of love.

Of thyself forgetful still,

All who dwell around thee bless, Heedful of thy Maker's will,

Beautiful in lowliness.

Long may faithful Memory dwell On thy virtues fond and true, And Affection's tablet tell Where the stainless Lily grew. 
18

VOICE OF FLOWERS.

\section{FLORA'S PARTY.}

LADY FLORA gave cards for a party at tea, To flowers, buds, and blossoms of ev'ry degree; So from town and from country they thronged at the call,

And strove, by their charms, to embellish the hall.

First flock'd the exotics, with ornaments rare, The tall Oleander and Heliotrope fair;

Camella, resplendent with jewels new set, And changeful Hydrangia, the heartless coquette.

The Tulips came flaunting in gaudy array, With Hyacinths, bright as the eye of the day; Dandy Coxcombs and Daffodils, proudly polite, With their dazzling red vests, and their corsets laced tight ;

While the Soldiers in Green, cavalierly attired,

Were all by the ladies extremely admired; But the beautiful Lily, with bosom of snow, Complain'd that those officers star'd at her so, She was strangely confus'd, and would like to be told

What they saw in her manners that made them so bold. 
There were Myrtles and Roses from garden and plain,

And Venus's Fly Trap, they brought in their train;

So the beaux cluster'd round them, they hardly knew why,

At each smile of the lip, or each glance of the eye.

Madame Damask a robe had frum Paris brought out,

The envy of all who attended the rout;

Its drapery was folded, her form to adorn,

And clasp'd at the breast with a diamond-set thorn.

Yet she, quite unconscious, 't would seem, of the grace

That enchanted all groups who frequented the place,

Introduced, with the sweetest of words in her mouth,

The young Multiflora, - her guest from the South.

Neighbor Cinnamon prated of household and care,-

How she seldom went out, even to breathe the fresh air ; 
20

VOICE OF FLOWERS.

There were so many young ones and servants to stray,

And the thorns grew so fast if her eye was away :

"Cousin Moss-Rose," she said, "you who live like a queen,

And ne'er wet your fingers, scarce know what I mean."

So that notable lady went on with her lay, 'Till the auditors yawned, and stole softly away.

The sweet Misses Woodbine, from country and town,

With their brother-in-law, Colonel Trumpet, came down;

And Lupine, whose azure eye sparkled with dew,

On Amaranth leaned, the unchanging and true;

While modest Clematis appeared as a bride, And her husband, the Lilac, ne'er moved from her side-

Tho' the Dahlias all giggled, and said, "'T was a shame

For a young married chit, such attention to clairn ; 


\section{FLORA'S PARTY.}

They had travell'd enough, in all conscience, to tell

What the ton was abroad, where the great people dwell,

But were ne'er at a ball, or soiree in their life, Where a city-bred gentleman spoke to his wife."

Mrs. Piony came in, quite late, in a heat, With the Ice-plant, new-spangled from forehead to feet,

Lobelia, attired like a queen in her pride, And the Larkspurs, with trimmings new furbished and dyed,

And the Blue-bells and Hare-bells in simple array,

With all their Scotch cousins, from highland and brae.

Acacias and Marigolds clustered together, And gossiped of scandal, the news, and weather,

What dresses were worn at the wedding so fine

Of Counsellor Thistle, and fair Columbine ; Of the loves of Sweet-William, and Lily, the prude,

'Till the clamors of Babel again seem'd renewed. 
In a little snug nook sate the Jessamine pale, And that pure, fragrant Lily, the gem of the vale ;

The meek Mountain-Daisy, with delicate crest,

And the Violet, whose eye told the Heaven in her breast ;

While allur'd to their side, were the wise ones, who bow'd

To that virtue which seeks not the praise of the crowd.

But the proud Crown Imperial, who wept in her heart

That modesty gained of such homage a part, Looked haughtily down on their innocent mein,

And spread out her gown, that they might not be seen.

The bright Lady-slippers, and Sweet-briars agreed

With their slim cousin Aspens a measure to lead;

- And sweet 't was to see their light footsteps advance,

Like the wing of the breeze, thro' the maze of the dance; 
But the Monk's-hood scowl'd dark, and in utterance low,

Declared "'t was high time for good Christians to go;"

He'd heard from the pulpit a sermon sublime, Where 't was proved from the Vulgate- "To dance was a crime."

So, wrapping a cowl round his cynical head, He snatch'd from the side-board a bumper, and fled.

A song was desired, but each musical flower Had "taken a cold, and 't was out of her power ;"

'Till sufficiently urged, they burst forth in a strain

Of quavers and trills, that astonished the train. Mimosa sat shrinking, and said, with a sigh, "'T was so fine, she was ready with rapture, to die ;"

And Cactus, the grammar-school tutor, declared

"It might be with the gamut of Orpheus compared."

But Night-shade, the metaphysician, complained

That " the nerves of his ears were excessively pained; 


\section{4}

VOICE OF FLOWERS.

'T was but seldom he crept from the college," he said,

"And he wished himself safe in his study, or bed."

Lady Flora, 't was thought, had a taste for design,

And her skill in embroidery all felt to be fine; So the best of her pictures, for tinting and shade,

Were all on this pleasant occasion displayed. Her visitors vied in expressions of praise, And exhausted the store-house of elegant phrase ;

Tho' some grave connoisseurs in a circle must draw,

Their acuteness to show by detecting a flaw.

Miss Carnation took her eye-glass from her waist,

And pronounc'd they were scarce in goodkeeping, or taste,

While prim Fleur de lis in her robe of French silk,

And magnificent Calla, with mantle like milk, Of the Louvre recited a wonderful tale, And how "Guido's rich tints made dame Nature look pale.” 


$$
\text { FLURA'S PARTY. }
$$

Signor Snow-Ball assented, and ventured to add

An opinion, that " all Nature's coloring was bad;"-

He had thought so, e'er since a short period he spent,

To muse on the paintings of Rome, as he went

To visit his friend Rhododendron, who chose An abode on the Alps, in a palace of snows. But he took, on Mont Blanc, a most terrible chill,

And since his return had been pallid and ill.

Half-wither'd Miss Hackmetack studied her glass,

And hop'd with her cousins, the Spruces, to pass ;

But Ivy, the sage antiquarian, who knew Every' cycle, 'twas said, that Chronology drew, Thro' his near-sighted optics, descrying her late,

Discompos'd her, by asking some aid in a date ; So she pouted her lips, and said, tartly, with scorn,

She "could not remember before she was born." 
26

VOICE OF FLOWERS.

Old Jonquil, the crooked-back'd beau, had been told,

That a tax would be laid on old bachelors' gold,

So he lac'd down his hump, pre-determined to try

The long disus'd weapons of Cupid, so sly, Sought out half open'd buds in their infantine years,

And ogled them all, till they blushed to their ears.

Philosopher Sage, on a sofa was prosing, With good Dr. Chamomile quietly dozing, Though the Laurel descanted, with eloquent breath,

Of heroes and battles, of victory and death; Of the conquests of Greece, and Bozzaris, the brave,-

" He had trod in his footsteps, and sigh'd o'er his grave."

Farmer Sunflower stood near, entertaining a guest,

With the crops he had rais'd, and the cheeses he prest; 


\section{FLORA'S PARTY.}

For the true-hearted soul deem'd a weatherstained face,

Or a toil-harden'd hand, were no marks of disgrace.

Then he beckon'd his nieces to rise from their seat,

The plump Dandelion, and Butter-cup neat, And bade them to "pack up their duds, and away,

He believ'd in his heart 'twas the break of the day.

"And high time it is, for good people," said he,

"At home, and in bed, with their households to be."

'Twas indeed very late,-and the coaches were brought,

For the grave matron flowers of their nurseries thought;

The lustre was dimmed of each drapery rare, And the lucid young brows looked beclouded with care ;

All, save the bright Cereus,- that nymph so divine,

Who preferr'd through the curtains of midnight to shine : 
28

VOICE OF FLOWERS.

Now with congees, and curtseys, they moved to the door,

But the White Poppy nodded ere parting was o'er,

For Night her last candle was snuffing away, And Flora grew tired, though she begged them to stay ;

Exclaimed, "all the watches and clocks were too fast,

And old Time fled in spite, lest her pleasure should last."

Yet when the last guest went, with daughter and wife,

She vowed she "was never so glad in her life ;"

Called out to her maids, who with weariness wept,

To "wash all the glasses and cups ere they slept,

For Aurora, that pimp, with her broad staring eye,

Would be pleas'd, in her house, some disorder to spy."-

Then drank some pure honey-dew, fresh from the lawn,

And with Zephyrons hastened to sleep until dawn. 
THE TULIP AND EGLANTINE.

THE TULIPAND EGLANT I N E .

The Tulip called to the Eglantine; "Good neighbor, I hope you see How the throngs that visit the garden come To pay their respects to me.

"The florist admires my elegant robe, And praises its rainbow ray,

Till it seems as if, through his raptured eyes He was gazing his soul away."

"It may be so," said the Eglantine; "In a humble nook I dwell, And what is passing among the great, I cannot know so well.

But they speak of me, as the flower of love, And that low, whispered name, Is dearer to me, and my infant buds, Than the loudest breath of fame." 
VOICE OF FLOWERS.

TH E BLOS SOM A N D THE BEA U T I F U L .

To a bright bud, with heart of flame, The angel of the seasons came, Took its close-shrouding hood away, And rais'd its forehead to the day,And from its blushing depths updrew A stream of incense, fresh as dew.

He kiss'd its cheek, and went his way, And then a form, with temples grey, Crept to its side, and taught it how To shrink, to shrivel, and to bow,On the cold earth its lip to lay, And mix with fair things pass'd away.

Thus, to a maid, in beauty's spring, Love's angel came, on radiant wing, Nerv'd the light foot to skim the plain, And made the voice a music strain,And wreath'd his cestus round her breast, Till every eye her power confest. 
THE BLOSSOM AND THE BEAUTIFUL. 31

A ghastly shade, with lifted dart.

Strode to her couch, and chill'd her heart.

Pale grew the brow, which roses fir'd;

And the soft breath in sighs expir'd:

Yet that which bound her to the sky

Escap'd his shaft. It could not die.

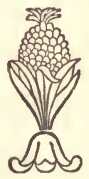


VOICE OF FLOWERS.

\section{THE S NOW DROP.}

A Dedication for an Annual with that title.

WHEN infant Spring, with a glance of fear, Doth tread in the steps of the Winter drear, And beckon the streams on the frosted plains To loosen the links of their icy chains,

Ere yet the Violet hath dar'd to show Its timid head through the wasting snow, While Tulip and Dahlia on couches deep, In their bulbous night-caps, are fast asleep, Like beauties fatigued at the midnight rout, Who shut the sun, with their curtains, out,At the earliest call of the blue-bird sweet, I venture forth through the mist and sleet, And haste to bring, with my simple cheer, The first glad wish of the new born year. But now from Autumn, a boon I bear, Of varied tint, and a perfume rare,Taste hath wander'd through grove and bower, The bird to win, and to cull the flower, And to gather them close in a charmed ring, And to bind them fast with a silken string; Friendship doth offer the gift to thee,Pure and warm may its guerdon be. 
THE CACTUS SPECIOSISSIMUS.

THE CACTUS SPCIOSISS I M U S.

Wно hung thy beauty on such rugged stalk, Thou glorious flower?

Who poured the richest hues, In varying radiance, o'er thine ample brow, And, like a mesh, those tissued stamens laid Upon thy crimson lip?

\section{Thou glorious flower!}

Methinks it were no $\sin$ to worship thee, Such passport hast thou from thy Maker's hand,

To thrill the soul. Lone, on thy leafless stem, Thou bidd'st the queenly rose, with all her buds,

Do homage, and the greenhouse peerage bow Their rainbow coronets.

\section{Hast thou no thought?}

No intellectual life? thou who can'st wake Man's heart to such communings? no sweet word

With which to answer him? 'T would almost seem 
That so much beauty needs must have a soul, And that such form as tints the gazer's dream, Held higher spirit than the common clod On which we tread.

Yet while we muse, a blight Steals o'er thee, and thy shrinking bosom shows

The mournful symptoms of a wan disease.I will not stay to see thy beauty fade.

- Still must I bear away within my heart Thy lesson of our own mortality ;

The fearful withering of each blossomed bough On which we lean, of every bud we fain Would hide within our bosoms from the touch Of the destroyer.

So instruct us, Lord !

Thou Father of the sunbeam and the soul, Even by the simple sermon of a flower, To cling to Thee. 
THE DAHLIA AND VERBENA.

35

\section{THE DAHLIA AND VERBENA.}

A TALL and richly drest Dahlia boasted. She lifted up her head haughtily, as though she felt herself a queen. Herlips moved, and she was heard thus to soliloquize :-

"I alone, of all the flowers around, am truly beautiful. Which of them can compare with me, in elegance of dress, or dignity of deportment?

Yet I suffer for want of society. I cannot associate with those around, who are destitute of my accomplishments.

Here is an insipid Verbena at my feet, always trying to be sociable. She is so ill-bred as to smile, when I meet her eye, as if she were an acknowledged acquaintance.

It is in vain that I strive to convince her of her vulgarity. I cannot even look down without seeing her. I wish she would move away, and give place to some neighbor, more proper for one of my rank.

I doubt whether she even knows that my name is Lady Liverpool. I will throw her 
a withering frown, and see if it is not possible to repel her advances."

That night there came an early frost. The splendid robes of the Dahlia were ruined by its chilling touch. She hung her head in bitterness, and was ashamed to be seen.

But the little pale-cheeked Verbena, whom she had so long despised, looked meekly up, and spoke kind and cheering words. It had been sheltered from the frost by the drapery of its proud neighbor.

Forgetting the disdainful demeanor of the Dahlia, it tenderly ministered to its sorrows, and sent up its sweetest perfumes, to cheer her, like a cloud of incense.

And as I bent down, admiring its sympathy, there seemed to come from its meek exainple, a gentle voice, "Go thou and do likewise." 
THE DESERT FLOWER.

THE DESERT FL OW ER.

A WEARY course the traveller held, As on with footstep lone, By scientific zeal impelled, He tracked the torrid zone.

Sad thought was with his native glades, His father's pleasant halls, Where darkly peer, through woven shades, The abbey's ivied walls.

Yet to the far horizon's bound, Far as the glance could sweep, The sandy desert spread around, Like one vast, waveless deep.

What saw he 'mid that dreary scene, To wake his rapture wild?

A flower! A flower! with glorious mien, Like some bright rainbow's child. 
Kneeling, he clasped it to his breast, He praised its wondrous birth, Fair, fragile, beautiful, and blest, 'The poetry of earth.

No secret fountain through its veins Sustaining vigor threw, No dew refreshed those arid plains, Yet there the stranger grew.

It seemed as if some tender friend, Beloved in childhood's day, A murmur through those leaves did send, A smile to cheer his way;

And fervently a prayer for those, In his own distant bower,

Like incense from his heart uprose, Beside that Desert Flower.

For thus do Nature's hallowed charms Man's softened soul inspire, As to the infant in her arms, The mother points its sire. 
MINERVA'S PRIZE.

\section{MINERVA'S PRIZE.}

Minerva, a visit to Flora once made,

When the flowers, in a body, their compliments paid,

And, charmed with their manners, and elegant dyes,

Desired she might give to the fairest $a$ prize ; Appointing a day, when herself should preside, And on their pretensions to beauty decide.

Then the Rose bridled up, with a confident air,

As if she would say,-Who with me shall compare?

While the Lily, but newly come out as a bride, Whisper'd low to her sisters, and laugh'd at such pride.

The Hyacinth studied her wardrobe with care, Still puzzled to settle what colors to wear; The Poppy, ashamed of her dull, sleepy eyes, Wore a new scarlet dress, with a view to the prize. 
40

VOICE OF FLOWERS.

Then flock'd the Anemones, fair to behold, With the rich Polyanthus, in velvet and gold; And the Tulip came flaunting, and waving her fan,

And turned up her nose at the Daffodil clan. The buds who were thought by their mothers too young,

Round their sister's toilettes discontentedly hung;

There was teazing, and dressing, and prinking enough-

The pretty Quill-Daisies each bought a new ruff;

The stately Carnations stood frizzing their hair, And the tall London-pride, choosing feathers to wear.

The Pink at her mirror was ready to drop, And the Snow-ball bought rouge at a milliner's shop ;

While in the same square, at a shoe-store so neat,

The trim Lady-Slippers were pinching their feet.

Thrifty Lilac acknowledg'd her robe was not new,

But with turning and furbishing thought it might do ; 
While the queer Ragged-Lady, who pass'd for a poet,

Sat darning her hose, and wish'd no one to know it;

And Fox-Glove, who sometimes had furnished a sonnet,

Was tying new bows on a fanciful bonnet.

The green-house exotics, in chariots, went by, For their delicate nerves feared each frown of the sky,

While from her low cottage of moss on the plain,

The Violet look'd up and admired the bright train,

Not thinking to join in a circle so gay, Or dreaming that she had a charm to display; Beside a sick bud she preferred to attend, Which down to the dust its pale forehead would bend.

But judge how this splendid conventicle stared, When Minerva the prize to the Violet declar'd ! Remarking, though beauties and graces were there,

That "Modesty ever to her was most fair."

And distinctly pronounced, in the hearing of all, That " the humble must rise, and the arrogant fall." 


\section{KING FROST, AND THE}

\section{GARDEN BEAUTIES.}

Tив Dahlia call'd to the Mignionette,

And what do you think she said?

"King Frost has been seen in the vale below," And she trembled and shook with dread.

"King Frost has been seen in the vale below, A marshalling forth his trainCaptain Gladiolus told me so, And brandish'd his sword in rain."

Then the Snow-Berry knock'd at the Woodbine's bower,

Affrighted, and out of breath:

"Pray, give me a draught of water," said she; "I am growing as pale as death."

"Ah me!" the gay Carnation cried, "The Rose, on her dying day,

Bade me prepare for this solemn hour, But I've trifled my time away." 
The Poppy complain'd that her sleep was broke By her neighbor's noise and fright ; And the Coxcomb said " 't was a burning shame To disturb a belle so bright."

Lady Larkspur nodded her graceful head, And beckon'd the fair Sweet-Pea,"Do you credit this terrible news, my dear?" "I think 't is but gossip," said she.

"Young Zephyr was here," said the Asters proud,

"He made us a morning call,

And if there had been any truth in the tale

He must surely have known it all :

"For the daily papers he always reads, As soon as they come from the press, And if King Frost were at any hotel, 'T would not be forgotten, we guess."

“" $T$ is doubtless a hoax," said the Sun-Flower tall,

"Don't you think that the higher powers Would have seen that I was appris'd, before These pert little radical flowers ?" 


\section{VOICE OF FLOWERS.}

Yet still, Mimosa was nervous and faint, And Convolvolus feared to stir,

And the Mourning-Widow wept, though long The world had been dark to her.

But Amaranth smil'd, with a changeless eye, And the Constancy rose unbow'd, For a deathless spirit of hope was theirs, And their trust was above the cloud.

That night, King Frost to the garden came, With all his legions dread, And laid the might of the proudest low, And left the fairest dead. 
TRANSPLANTED FLOWERS.

\section{TRANSPLANTED FLOWERS.}

THERE's many a flower that proudly springs Amid the gaudy world's parterre, Caress'd by Fashion's painted wings,

$$
\text { To Folly dear. }
$$

Whose flaunting petals woo the sun,

Heedless of Beauty's transient lot, But wither ere the day is done,

$$
\text { Unwept, forgot. }
$$

Yet some there are that bloom apart,

With meekly consecrated charm, Whose gifts of fragrance cheer the heart

$$
\text { Like healing balm. }
$$

O'er the blest spot, where erst they grew, The eye of Love its tears shall shed, And Pain and Penury bedew

Their funeral bed. 
But, Ti'ath an everlasting beam They smile, where no dark cloud descends; Theirs war that hallow'd incense stream, Which heavenward tends.

Unfading, lo! they live, they bloomTransplanted by His culturing hand, Who bade them seek beyond the tomb A better land.

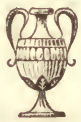


WILD FLOWERS, ETC.

WILD FLOWERS, GATHERED FOR A SICK FRIEND.

RISE from the dells where ye first were born, From the tangled beds of the weed and thorn; Rise, for the dews of the morn are bright, And haste away with your eyes of light. The greenhouse princes, with gathering frown, On your simple garbs may look haughtily down, Yet shrink not-His finger your heads hath bowed,

Who heeds the lowly, and humbles the proud. The tardy spring, and the frosty sky, Have meted your robes with a miser's eye, And checked the blush of your blossoms free; With a gentler friend your home shall be, To a kinder ear you may tell your tale Of the zephyr's kiss, and the scented gale. Ye are charmed! ye are charmed! and your fragrant sigh

Is health to the bosom on which ye die. 


\section{VOICE OF FLOWERS.}

GOS I P W I TH A SPRI N G

\section{B O U Q U T .}

SPEAK, speak, sweet guests,

Yes, ope your lips in words.

'Tis my delight to talk with you, and fain

I'd have an answer. I've been long convinced You understand me, - though you do not choose

To wear your bright thoughts on your fingertips,

For all to sport with.

Lily of the Vale,

And you, meek Violet, with your eyes of blue, I call on you the first,-for well I know How prone such village maidens are, to hide Their clear good sense among the city folks, Unless well urged, and fortified to speak.

- O purple Pansy ! friend of earliest years, You're always welcome. Have you never heard 
GOSSIP WITH A SPRING BOUQUET.

From some wise grandame, of your ancestors,

Who on the margin of my native Thames

Flourished, rnore vigorous and more fair than you?

'Twas not the fond garrulity of age,

That made her laud the past, without respect. To verity; for I remember well

How beautiful they were, and with what pride I used to pluck them, when my school was o'er,

And love to place them, rich with breathing sweets,

Between my Bible-leaves, and find them there Month after month, pressing their bosoms close To some undying hope.

Bright Hyacinth,

I'm glad you've brought your little ones. How snug

You wrap them in their hoods. But still I see Their merry eyes and their plump cheeks peep out.

Ah! here's the baby, in its blanket too:You're a good mother, sure. Don't be in haste To take their mantles off; the morn is chill; I'd rather see them one by one come forth, Just when they please. A charming family! 
50 VOICE OF FLOWERS.

And very happy you must doubtless be, In their sweet promise, and your matron care.

Gay, graceful Tulip, did you learn in France Your taste for dress? and how to hold your head

So elegantly? In the gale, yestreen, That o'er the parterre swept with sudden force, I thought I saw you waltzing. Have a care, And do not look disdainfully those You call plebian flowers, because, my dear, We live in a republic, where the strength Comes from beneath, and many a change occurs

To lop the haughty, and to lift the low.

Good neighbor Cowslip, I have seen the bee Whispering to you, and have been told he stays

Quite long and late, amid your golden cells. It must be business that he comes upon, Matter-of-fact, he never wastes an hour. Know you, that he's a subtle financier? And shows some gain for every day he spends? Oh! learn from him the priceless worth of time, 
GOSSIP WITH A SPRING BOUQUET. 51

Thou fair and frail! So shalt thou prove the truth,

That he who doth associate with the wise, Shall in their wisdom share.

Narcissus pale!

Had you a mother, child, who kept you close Over your needle or your music books? And never bade you sweep a room, or make A pudding in the kitchen? I'm afraid She shut you from the air, and fervid sun, To keep you delicate, or let you draw Your corset-lace too tight. I would you were As hardy as your cousin Daffodil, Who to the sharp wind turns her buxom cheek Unshrinking, like a damsel taught to spin, Or milk the cows, and knead the bread, and lead

A useful life, her nerves by labor strung To bear its duties and its burdens too.

Lilac of Persia! tell us some fine tale Of Eastern lands. We're fond of travellers. Have you no legend of some Sultan proud? Or old fire-worshipper? Not even one note Made on your voyage? Well, 'tis wondrous strange,

That you should let so rare a chance slip by, 


\section{VOICE OF FLOWERS.}

While those who never journeyed half so far, Fill sundry volumes, and expect the world To reverently peruse and magnify What it well knew before.

Most glorious Rose, You are the queenly belle. On you, all eyes Admiring turn. Doubtless you might indite Romances from your own sweet history. They're all the fashion now, and crowd the page

Of many a periodical. Wilt tell None of your heart adventures? Never mind!

All can detect the zephyr's stolen kiss In your deep blush; so, where's the use to seal

Your lips so cunningly, when all the world Call you the flower of love?

And now good-bye;A pleasant gossip have I had with you, Obliging visitants, but must away To graver toils. Still keep your incense fresh And free to rise to Him, who tints your brows, Bidding the brown mould, and unsightly stem Put forth such blaze of beauty, as translates To dullest hearts His dialect of love. 
HOLLYHOCK"AND HER VISITOR.

THE HOLLYHOCK AND HER VISITOR.

A LARGE bumble-bee often visited a stately hollyhock. He lingered in the deep red cup that she made for him, and talked busily with her. The neighboring flowers heard the full tones of his voice, but could not distinguish his words.

At length, a tall larkspur bent her ear, and listening closely, understood him to say, "I am very rich. I have gathered much pollen. I store it in a large wax palace, which I shall fill with honey. None of the bumble-bees in the village can compare with me."

"Oh, it must make you very happy," answered the hollyhock, "that when any poor, sick bees come and ask relief, you will have plenty for them, as well as yourself."

"I cannot undertake to feed them," he replied. "Every one must provide for himself. I worked hard to get what is mine. Let others go and do the same." 
"But will you be able to use all that you have laid up? And, if not, what good will it do you ?" asked the hollyhock, blushing more brightly from the earnestness with which she spoke.

"I never expect to use half of it, but I do not choose to give it away. What good will it do me to hoard it up, do you ask? Why, don't I hear people say, there goes the rich bumblebee? That pleases me."

"I will tell you how to get rich, too. Open your leaves wide when the sun shines, and gather all the beams you can, and keep them close in your secret chamber. Then, when the dews fall, and you have drank as much as possible, shut yourself up, and do not let a single drop escape on the buds below; so you will be sure to grow larger than they."

But the hollyhock said, "There is no avarice among flowers. - We take what our Father sends, and are glad. We do not wrinkle our brows with care, or grow old before our time."

The bumble-bee drew nearer still, and said, "You know nothing at all about the pleasures that wealth can bring. Listen! I think of setting up an equipage. I shall have two glowworms for postillions; you know their lamps 
HOLLYHOCK AND HER VISITOR.

will cost me nothing. But you must not breathe this, for I have not yet mentioned it to my wife."

The hollyhock replied with a clear voice, "There is neither meum nor tuum among the flower-people. We like to share with others the good things that come to us from above. It makes us happier than to sound a trumpet before us, and boast of riches with which we do no good."

Then the large bumble-bee seemed offended at his friend the hollyhock, and, buzzing in an angry tone, flew away. 


\section{6}

VOICE OF FLOWERS.

THE EVENING PRIMROSE.

Pale Primrose! lingering for the evening star To bless thee with its beam, like some farr child,

Who, ere he rests on Morpheus' downy car,

Doth wait his mother's blessing, pure and mild,

To hallow his gay dream. His red lips breathe The prompted prayer, fast by that parent's knee,

Even as thou rear'st thy sweetly fragrant wreath

To matron Evening, while she smiles on thee.

Go to thy rest, pale flower! The star hath shed His benison upon thy bosom fair, The dews of summer bathe thy pensive head, And weary man forgets his daily care : Sleep on, my rose ! till morning gilds the sky, And bright Aurora's kiss unseals thy tremblin? eye. 
THE CONSTANT FRIENDS.

THE CONSTANT FRIENDS.

O swEET soul'd flowers, with robes so bright Fair guests of Eden birth,

In changeful characters of light,

What lines of love divine ye write

Upon this troubled earth!

Man sinn'd in Paradise, and fell-

But when the storm arose-

When thorns and brambles sow'd his path, And gentlest natures turn'd to wrath,

Ye leagued not with his foes.

Ye sinn'd not, though to him ye clung,

When, at the guarded door,

The penal sword its terrors flung,

And warn'd him, with its flaming tongue,

To enter there no more. 
Forth by his side ye meekly far'd, With pure, reproachless eye, And when the vengeful lion roar'd, A balmy gush of fragrance pour'd, In hallow'd sympathy.

Ye sprang amid the broken sod,

His weary brow to kiss ;

Bloom'd at his feet where'er he trod, And told his burden'd heart of God, And of a world of bliss.

Ye bow'd the head, to teach him how He must himself decay ; Yet, dying, charged each tiny seed The earliest call of Spring to heed, And cheer his future way.

From age to age, with dewy sigh,

Even from the desert glade, Sweet words ye whisper, till ye die Still pointing to that cloudless sky, Where beauty cannot fade. 


\section{THE TEARS OF APRIL.}

\section{THE TEARS OF APRIL.}

"He who goeth forth and weepeth, bearing precious seed, shall doubtless come again with rejoicing, bringing his sheaves with him."

QUEEN of the opening year, who weep'st to take

Thy slender sceptre o'er a loyal clime, Fearing a lot of royalty must wake

The wrinkle and the thorn before their time;

Be firm and hopeful! for the sparkling smile Shall kiss the transient tear-drop from thy cheek,

And in thy foot-prints spring with gentlest wile, The blushing primrose, and the violet meek.

The snow-drop pure shall don its mantle green, And balmy skies awake their favoring ray, And heralds, bright with plumage, bless the queen,

Who joins a tender heart to regal sway.

So go thou forth, with tears, thy precious seed Sowing in lowly trust, for Joy shall crown the deed. 


\section{PLANTING GERANIUM AND BOX}

ON THE GRAVE OF AN AGED FRIEND.*

Fragile plant, of slender form,

Fair, and shrinking from the storm,

Raise thou here, thy timid head,

Bloom in this uncultur'd bed :

Thou, of firmer spirit, too,

Stronger texture, deeper hue,

Dreading not the blasts that sweep,

Rise, and guard its infant sleep.

Fear ye not the lonely shade Where the bones of men are laid;

Short, like yours, their transient date,Keen hath been the scythe of fate.

Forth, like plants, in glory drest,

They came upon the green earth's breast, Spread forth their roots to reach the stream,Their blossoms, toward the rising beam,

- This tribute to the memory of a kind benefactress of childhood, though written in early years, seemed not inappro. priate to the present selection. 
Inhal'd the morning's balmy breath, And sank at eve, in withering death. Rest here, meek plants, for few intrude To break this silent solitude.

Yet should some giddy footstep tread Amid the ashes of the dead,

Still let the hand of rashness spare These tokens of affection's care, Nor pluck their cherish'd buds that wave, In sweetness o'er a Christian's grave.

- White were the locks that thinly spread Their silver o'er her honor'd head, And furrows, not to be effaced, Had time amid her features traced, Before my earliest strength I tried In infant gambols by her side ; But yet, no grace or beauty rare, Were ever to my eye so fair.

Seven times the sun with swift career, Hath marked the circle of the year, Since first she pressed her lowly bier; And seven times sorrowing have I come Alone and wandering through the gloom, To pour my lays upon her tomb; Nor could I bear to see her bed With brambles and with thorns o'er spread. 
62

VOICE OF FLOWERS.

Ah! surely round her place of rest I should not let the coarse weed twine, Who every path by sorrow prest, With pure benevolence hath blest, And scattered such perfumes on mine ; It is not meet, that she should be Forgotten, or unwept by me.

My plants, that in your hallowed beds, Like strangers, raise your trembling heads, Drink the pure dew that evening sheds, And meet the morning's earliest ray, And catch the sunbeams when they play; And if your cups are filled with rain, Shed back those drops in tears again; Or if the gale that sweeps the heath, Too roughly o'er your leaves should breathe, Then sigh for her, and when ye bloom, Scatter your fragrance o'er her tomb.

But should ye, smit with terror, cast Your blighted blossoms on the blast, Or faint beneath the vertic heat, Or fail when wintry tempests beat, There is a plant of deeper bloom, Whose leaves shall deck this honor'd tomb, Not blanch'd with frost, or parch'd for rain, Or by the wrath of winter slain, 
PLANTING GERANIUM, ETC.

But every morn its buds renewed, Are by the tears of evening dewed, - The deathless plant of gratitude.

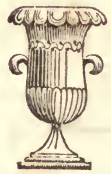




\title{
64 VOICE OF FLOWERS.
}

\section{FORGOTTEN FLOWER S.}

\author{
TO A BRIDE. *
}

We were left behind, but we would not stay, We found your clue, and have kept the way, For, sooth to say, the track was plain, Of a bliss like yours in a world of pain. How little we thought, when so richly we drest,

To go to your wedding, and vie with the best, When we made our toilette with such elegant care,

That we might not disgrace an occasion so rare; To be whirl'd in a coach at this horrible rate, From county to county, and State to State! Though we travel'd incog. yet we trembled with fear,

For the accents of strangers fell hoarse on our ear.

- An elegant bouquet, sent as a nuptial present, arrived just as the bride had taken her departure for her new home in a neighboring State, and were sent after her, in the stage coach, and reached her without injury, in the depth of winter. 
FORGOTTEN FLOWERS.

We could hear every word, as we quietly lay, In the snug box of tin, where they stow'd us away,

And how would our friends at a distance have known,

If charm'd by our beauty, they'd made us their own?

All unus'd to the taverns, and roads, as we were,

Our baggage and bones were a terrible care, But we've scap'd every peril, the journey is o'er,

And hooded and cloak'd, we are safe at your door.

We bring you a gift from your native skies, The chrystal gem from Affection's eyes, Which tenderly trickles, when dear ones part, We have wrapp'd it close in the rose's heart; We are charged with a mother's benison kiss ; Will you welcome us into your halls for this? We are chilled with the cold of our wintry way,

Our message is done, we must fade away, Let us die on your breast, and our prayer shall be,

An Eden's wreath for thy love and thee. 


\section{A CIRCLE OF FRIEN DS * COMPARED TO FLOWERS.}

Go seek the choicest sweets that Nature fair Hath kindly trusted to the culturer's care,Unfolding buds, with vernal dew-drops pure, Resplendent flowers, that summer suns mature,

-At the dissolution of a Literary Society, whose members (nine of each sex) were united in friendship as well as in intellectual pursuit, it was proposed that some emblematic poem should preserve the recollection of their pleasant intercourse. Thus the foregoing poem, which has been hitherto unpublished, was called into existence; and a beautifully painted bouquet was also executed by another member, in which the eighteen personified flowers were tastefully grouped.

The arbitrary signification of the inmates of Flora's realm not being as generally adopted at that period, as now, the selections in the foregoing lines were founded less upon those, than upon some supposed resemblance between the flowers and the character they typified. Now, at the expiration of a quarter of a century, during which the spoiler has not left our circle unvisited, some of the passages acquire interest, as being linked by tender associations to the memory of the departed and beloved. 
CIRCLE OF FRIENDS, ETC.

And changeless plants, whose firmer breasts defy

The frosts of autumn, or the wintry sky.

Bring first the thornless Rose, of colors rare, Fresh, bright, and graceful, from the florist's care,

That reared in bowers, where nought was ever found

To chill, depress, contaminate, or wound, Knows no dark art to rouse the breath of strife, And bears enchantment for the vale of life.

Mark well yon Lily, on its stately stem, Whose snowy leaves conceal a polish'd gem, Thou may'st not miss it in the loveliest train, Nor once beheld, forget its charms again; Go, bow to taste its fragrance, and request The favoring presence of the cherish'd guest. And thou, Mimosa, dear and trembling flower, Come from thy cell, - unshrinking leave thy bower;

No pressure rude, thy folded buds shall harm, No touch unkind thy tender leaves alarm; Though in the world's rough journey thou may'st fear

Unkindred spirits, none shall meet thee here; 
68

\section{VOICE OF FLOWERS.}

This gentle band are form'd with thee to feel, And well they prize what thou would'st fain conceal,

Come, loved and fearless, while our care shall set

Fast by thy side, thy sister Violet, Still cheerful, unobtrusive, and serene, To grace the high, or deck the lowly scene; High be his bosom honor'd who shall gain This as a solace, and a charm for pain. The Woodbine next, whose graceful tendrils twine

In sweet luxuriance round the parent vine, Whose heaven-born fragrance breathes reviving power,

'Neath dewy evening, or the summer shower, Shall bless our wreath, for this can teach to glow

The morn of pleasure, or the night of woe. Thou, too, pale Lily, leave thy native vale, And yield thine essence to our fresher gale, What though thy bending head no gaze would meet,

Thy perfume guides us to thy green retreat, Where lingering zephyrs round thee gently sigh,

And catch the tones of music as they fly. 
CIRCLE OF FRIENDS, ETC.

The orange Cowslip, pure in heart, and gay, Bestows its beauty on our fair bouquet, Known by its sweetness, for its worth approv'd,

If seen, remember'd, if remember'd lov'd.

And there, "wee, modest, crimson-tipped flower,"

Meek Mountain Daisy, pride of friendship's bower,

Come all unconscious of thy winning grace, And lend thy lusture to our charmed vase.

Wilt thou, bright Pink, all graceful as thou art,

Still 'mid our circle form a cherish'd part? Or wouldst thou rather, in thy native glade, Reserve thine incense for the healer's aid?

From beauty's sheltered sphere roam onward wide,

Invoking forms of loftier strength and pride, That while the house-plants round the hearth shall glow,

As future years the varied lot bestow,

Perchance strong conflict with the storm may wage,

Or tower, the master spirits of the age. 
Why do we ask the Laurel here to glow? Is it that fame or glory blind us? No!

But that it hath a spirit nobly bold, To bide the blast, or brave the tempest cold. Not train'd by art, or nursed in idle ease, Or taught to bow to what the world shall please, But independent, and to honor true, Might guard the weak, and charm the tasteful too.

One, too, there is, whose latent virtues claim Of constancy, the undisputed name ; Who seeks, by shrinking in his favorite cell, The applause to shun, that he deserves so well; Yet all in vain, for few can fail to prize The hues that change not with the changing skies.

Wilt thou, Oh Sage! from cloistered study deign

To heed our summons, and delight our train? "Cur moriator homo," * might we say, Dum salvia crescit in horto," but the lay,

- It would seem that the ancient Romans had a high respect for the salubrious properties of this plant, by the interrogative adage, "Why need any man die, who has Sage in his gar. den ?" 
CIRCLE OF FRIENDS, ETC.

Cramp'd by the unyielding chains of Saxon verse,

Suits not the Roman proverb, boldly terse;

Still more unworthy is this pencil faint, Thy many virtues, lenient Sage, to paint.

And thou, Geranium, half exotic, say, Why art thou from the ancestral halls away? Thou need'st no gift that nature did not lend, Or art improve, or cultivation blend: Yet if thou better lov'st a sunnier sky, Breathe there the fragrance that can never die.

The meek Narcissus next invites our care, With fragile stalk and efflorescence fair, Which anxious friendship fears will scarce endure

The world's contagion, with a brow so pure; Yet this, perchance, may bear the dangerous test,

For heaven's own spirit lives within its breast.

Lure from its home, 'mid green Vermonia's plain,

The English Holly to our classic train, That fearless, firm, and scorning all disguise, Where'er it dwells, points upward to the skies. 
The Lilac, prompt to heed the call of Spring, Shuns not the summons to our magic ring; We saw it o'er the way-side traveller cast Shade from the heat, and covert from the blast, Yet from the meed of fame retire, to throw Its wealth of fragrance on the vale below.

And shall the verdant Myrtle be forgot, All unassuming in its shaded spot?

Perchance we may not win its wreathing vine From Coke and Blackstone, where it fain would twine,

Yet might it be persuaded thus to cheer The glowing circle, it were welcome here.

The varied Tulip, versatile and gay, With colors changing to the changing ray, Attracts the stranger by its brilliant dye, And with rich tissue charms the studious eye, Yet better loves in southern climes to bide, Than hear the accents of our praise or pride.

Now bind the treasur'd sweetness.

Do you say

That aught is wanting? There are none away. A plant there is, indeed, from mountains lone,

But blossom, flower, or fragrance, it hath none; 
CIRCLE OF FRIENDS, ETC.

Yet since ye call it forth, with friendship kind, It hath a tendril round your stalks to bind, A rustic shoot, the forist ne'er could teach, Yet loves the brilliance it despairs to reach. 


\section{BLOSSOMS FALLING FROM}

\section{THE FRUIT-TREES.}

TuE world doth take us captive with its wiles Of vanity or pleasure. So our thoughts Are searce in unison with Nature's grief, When her sweet blossoms fade.

\section{Yon stricken trees,}

From whence glad Autumn gathereth plentcous store

Of ruddy apples for the wintry eve, Resign their radiant robes, and rich perfume, That made the orchard like a queen's levee, And clad in russet garments, fleck'd with green, Lamenting, teach the philosophic lore Of brief prosperity.

\section{That lofty pine,}

Which, like some feudal baron from his tower, Did awe the neighboring peasantry of shrubs, Deplores that they should see his boasted wealth

Stripp'd by each robber breeze. 
BLOSSOMS FALLING, ETC.

$\Lambda$ tint like snow, from the young $\Lambda$ mond's charms

Strew'd lavishly around; while, sick at heart, The Peach, despairing mother, sees her balues Dead at her feet.

\section{Break forth in song, ye birds,}

From your cool nests, or on the buoyant wing, And be their comforters.

\section{Uphold their hearts}

With cheering deseant of the season's prime, When their bereavement shall be lost in joy. 'Tell them that man, their culturer, oft beholds His beauty and his pride, like theirs, depart; But yet, from what he counted loss, doth reap $\Lambda$ more enduring gain.

\section{Yea, bid them bide}

In faith and hope, the chastening of this hour, Yielding their fragrance to the tyrant windsFor God remembereth them.

\section{Lift high your strain,}

Minstrels of Heaven, and ask the sorrowing trees

If those pale petals fell not, where would be The glory of their fruitage? or the praise Of the Great Master at the Harvest Day? 


\section{THE W ILLOW, POPPY, AND VIOLET.}

A CHILD held in his hand a slight, leafless bough. It was like a supple, green wand. But it had been newly cut from the parent stock, and life still stirred in its little heart.

He sougbt out a sheltered spot, and plarited it in the moist earth. Often did he visit it, and when the rains of summer were witheld, he watered it at the cool sunset.

The sap, which is the blood of plants, began to flow freely through its tender vessels. A tiny root, like a thread, crept downwards, and around the head was a bursting forth of faint green leaves.

Seasons passed over it, and it became a tree. Its slender branches drooped downward to the earth. The cheering sun smiled upon them-the happy birds sang to them-but they drooped still. 
WILLOW, POPPY, AND VIOLET.

"Tree, why art thou always so sad and drooping? Am not I kind unto thee?" But it answered not-only as it grew on it drooped lower and lower, for it was a weeping willow.

The boy cast seed into the soft garden mould. When the time of flowers came, a strong, budding stalk stood there, with coarse, serrated leaves. Soon a full red poppy came forth, glorying in its gaudy dress. At its feet grew a purple violet, which no hand had planted or cherished.

It lived lovingly with the mosses, and with the frail flowers of the grass, not counting itself more excellent than they.

"Large poppy, why dost thou spread out thy scarlet robe so widely, and drink up all the sunbeams from my lowly violet?"

But the flaunting flower replied not to him who planted it. It even seemed to open its rich silk mantle still more broadly, as though it would have stifled its humble neighbors. Yet nothing hindered the fragrance of the meek violet.

The little child was troubled, and at the hour of sleep he spake to his mother of the tree that continually wept, and of the plant that overshadowed its neighbor. So she took 
78

VOICE OF FLOWERS.

him on her knee, and spake so tenderly in his ear, that he remembered her words when he became a man.

"There are some, who, like the willow, are weepers all their lives long, though they dwell in pleasant places, and the fair skies shine upon them in love. And there are others, who, like the poppy that thou reprovedst, are proud at heart, and despise the humble, whom God regardeth."

"Be thou not like them, my gentle child; but keep ever in thy breast the sweet spirit of the lowly violet, that thou mayest come at last to that blessed place, which pride cannot enter, and where the sound of weeping is unknown."

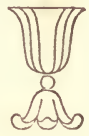


THE EARLY FROST.

\section{THE EARLY FROST.}

Mx flowers,-my few and precious flowers, what evil hath been here?

Came the fierce Frost-King forth last night, so secret and severe?

I saw you last with diamond dew fresh on each beauteous head,

And little deem'd to find ye thus, all desolate and dead.

White Poppy, tall and full of pride, whose petals' feathery grace

With fully rounded orb has decked my simple parlor vase ;

Thy oozing buds disclose the gum, that swells Hygeia's store,

But the sleep of death is on thee now, thy magic spell is o'er. 
80

VOICE OF FLOWERS.

Alas, my brave Crysanthemum, how crisp thou art, and sere;

Thou wert, perchance, too lightly prized, when gaudier friends were near;

Yet, like a hero didst thou rise, to meet the spoiler's dart,

And battle, till the pure life-blood ran curdling round thy heart.

My poor Sweet-Pea, my constant friend, whene'er I sought in vain

To twine a full bouquet for one who pressed the couch of pain;

Or when my garden sometimes failed my mantel-piece to dress,

Thou always gav'st a hoarded gem, to help me in distress.

But thou, dear lonely Pansy, thus smiling in my path,

I marvel much how thou hast scap'd the tyrant's deadly wrath;

Didst thou hide beneath thy neighbor's robe, so flaunting and so fine,

To bid one sad good-morning more, and press thy lips to mine? 
Good bye, my pretty flowering Bean, that with a right good wili,

O'er casement, arch and trellis went climbing, climbing still,

Till the stern destroyer marked thee, and in his bitter ire,

Quenched out thy many scarlet spikes that glowed like living fire.

Pale, pale Snowberry, all is gone; I would it were not so,

Methinks the Woodbine near thee hath felt a lighter woe ;

Lean, lean upon her sheltering arm, thy latest pang to take,

And yield to autumn's stormy will, till happier seasons wake.

Coarse Marigold, in days of yore, I scorned thy tawny face,

But since my plants are frail and few, I've gave thee welcome place,

And thou, tall London-pride! my son from weeds preserved thy stem,

And, for his sake, I sigh to see thy fallen diaadem. 
82

VOICE OF FLOWERS.

I have no costly Dahlias, nor greenhouse flowers to weep,

But I passed the rich man's garden, and the mourning there was deep,

For the crownless queens, all drooping, hung amid the wasted sod,

Like Boadicea, bent with shame, beneath the Roman rod.

'Tis hard to say farewell, my plants, 'tis hard to say farewell ;

The florist might despise ye, yet your worth I cannot tell ;

For at rising sun, or even-tide, in sorrow or in glee,

Your fragrant lips have ever op'd, to speak good words to me.

Most dear ye were to him who died, when summer round ye play'd,

That good old man, who looked with love on all that God had made;

Who, when his first familiar friends sank down in dreamless rest,

Took nature's green and living things more closely to his breast. 
My blessed sire, we bore his chair at early summer morn,

That he might sit among your bowers and see your blossoms born;

While meek and placid smiles around his reverend features played,

The language of that better land, where ye no more shall fade.

Shall I see you, once again, sweet flowers, when Spring returneth fair,

To strew her breathing incense upon the balmy air?

Will you lift to me your infant heads? For me with fragrance swell?

Alas! why should I ask you thus, what is not yours to tell.

I know, full well, before your buds shall hail the vernal sky,

That many a younger, brighter brow, beneath the clods must lie ;

And if my pillow should be there, still come in beauty free,

And show my little ones the love that you have borne to me. 
84 VOICE OF FLOWERS.

Yea, come in all your glorious pomp, ambassadors, to show

The truth of those eternal words that on God's pages glow,

The bursting of the icy tomb, the rising of the just

In robes of beauty and of light, all stainless from the dust.

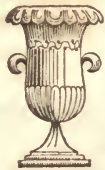


THE STRANGER'S FLOWER.

THE STR A NGER'S FLOWER.

In some of the South American republics, it was customary for ladies to present a flower to every stranger whom they received as a guest.

STRANGER ! new flowers in these vales are seen,

With a dazzling eye, and a fadeless green, They scent the breath of the dewy morn, They feed no worm, and they hide no thorn, But revel and glow in our balmy air ; They are flowers that freedom hath planted there.

This bud of welcome to thee we give; Bid its glowing blush in thy bosom live; It shall charm thee from all a stranger's pain, Reserve, suspicion, and dark disdain; $A$ race in its freshness and bloom are we, Bring no cares from a worn out world with thee. 
86 VOICE OF FLOWERS.

Tis a little time since the lance and spear, And the clamor of war and death were here; Our siesta the shout of the murderer broke, And we struggled to rend a tyrant's yoke, Till our midnight slumbers were pale with fears,

And the fairest cheeks bore a mourner's tears.

But now on the couch of its mother's breast, The infant sleeps long in its dream of rest, And the lover beneath the evening star, Woos the young maid with his light guitar; These are the blessings that wait the free, And stranger! this flower is our gift to thee. 
THE LILY'S WHISPER.

\section{THE L I L Y'S WH IS PER.}

"Bow down thy head, thou born of clay,Bow down thy head to me,"

A drooping Lily seemed to say, As sank the footsteps of the day,

Upon the grassy lea.

Its dewy lips to mine I prest,

And drank its stifled sigh,

A tear-drop lay within its breast,-

"Hast thou a woe to be confess'd, Thou favorite of the sky?"

"Two buds beside my heart awoke, More pure than opening day,But lo! a hand with sudden stroke From my embrace those idols broke, And bore them hence away." 
88

VOICE OF FLOWERS.

Still deeper seem'd the Lily's tone

My listening ear to greet:

" Think not for sympathy alone

That thus to thee I make my moan,

Though sympathy is sweet;

"No. Be my wound thy lesson made,

We love your nobler race,

Whose lot it is like ours to fade,

Like ours, to see in darkness laid

Your blossom's wither'd grace.

" So, let the Will Supreme be blest, And still with spirit meek,

Shut rebel tear-drops in your breast,

And wear, as badge of Heaven's sweet rest

Its smile upon your cheek."

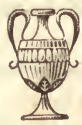


PLANTING FLOWERS, ETC.

\section{PLANTING FLOWERS ON THE}

\section{GRAVE OF PARENTS.}

I've set the flow'rets where ye sleep,

Father and mother dear;

Their roots are in the mould so deep,

Their bosoms hide a tear;

The chrystal of the dewy morn

Their trembling casket fills,

Mixed with that tear-drop from the heart,

Which filial love distils.

Above thy pillow, mother dear,

I've placed thy favorite flower-

The bright-eyed purple violet,

That deck'd thy summer bower;

The fragrant chamomile, that spreads

Its leaflets fresh and green,

And richly broiders every niche

The velvet turf between. 
I kissed the tender violet, That droop'd its stranger head, And called it blessed, thus to grow

So near my precious dead, And when my venturous path shall lead Aczoss the deep blue sea,

I bade it in its beauty rise And guard that spot for me.

There was no other child, my dead! This sacred task to share; Mother! no nursling babe beside, E'er claim'd thy tenderest care. And father! that endearing name,

No other lips than mine E'er breathed to prompt thy hallow'd prayer At morn or eve's decline.

Pluck not those flowers, thou idle child, Pluck not the flowers that wave In sweet and simple sanctity Around this humble grave, Lest guardian angels from the skies, That watch amid the gloom, Should dart reproachful ire on those Who desecrate the tomb. 
PLANTING FLOWERS, ETC.

Oh, kindly spare my plants to tear, Ye groups that wander nigh, When summer sunsets fire with gold The glorious western sky :

So when you slumber in the dust, Where now your footsteps tread, May griev'd affection train the rose Above your lowly bed.

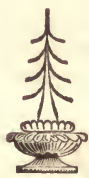




\section{ALPINE FLOWERS.}

MEeK dwellers 'mid yon terror-stricken cliffs, With brows so pure, and incense-breathing lips,

Whence are ye?

Did some white-wing'd messenger,

On Mercy's errands, trust your timid germ To the cold cradle of eternal snows?

Or, breathing on the callous icicles, Bid them, with tear-drops, nurse ye?

\section{Tree, nor shrub}

Dare yon drear atmosphere. No polar pine Uprears a veteran front. Yet there ye stand, Leaning your cheeks against the thick-ribb'd ice,

And looking up, with trustful eyes, to Him Who bids you bloom, unblanch'd, amid the waste

Of desolation. 


\section{Man, who panting toils}

O'er slippery steeps; or, trembling, treads the verge

Of yawning gulfs, from which the headlong plunge

Is to eternity, looks shuddering up, And marks ye in your placid loveliness, Fearless, yet frail; and, clasping his chill hands,

Blesses your pencil'd beauty. Mid the pomp Of mountain-summits, towering to the skies, And chaining the rapt soul in breathless awe, He bows to bind you drooping to his breast, Inhales your fragrance on the frost-wing'd gale,

And freer dreams of Heaven.

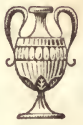


94

VOICE OF FLOWERS.

\section{THE ROSE-GERANIUM.}

COMPANION OF A VOYAGE.

HoLd up thy head, thou timid voyager!

Vex'd by the storm-clouds, as they darkly roll,

And by the fiercely tossing waves, that stir Thy slender root, and try thy trembling soul.

Sad change from thy sweet garden, where the dew

Each morning glisten'd in thy grateful eye, And where no rougher guest thy bosom knew, Than quiet bee, or gadding butterfly.

It grieves me sore to see thy leaflets fade, Wearing the plague-spot of the ocean spray, And know what trouble I for thee have made,

Who bore thee from thy native haunt away; Though, in thy life, I seem to hold the chain Of home and its delights, here on the pathless main. 
THE EMIGRANT DAISY.

THE EMIGRANT DAIS $\mathrm{Y}$.

ONCE, from its home in England's * soil, A daisy's root I drew, Amid whose moistened crown of leaves A healthful bud crept through, And whispered in its infant ear That it should cross the sea, A cherished emigrant, and share A western home with me.

Methought it shrank, at first, and paled; But when on ocean's tide Strong waves and awful icebergs frowned. And manly courage died, It calmly reared its crested head And smiled amid the storm, As if old Magna Charta's soul Inspired its fragile form.

- This daisy was taken from the spot, often visited by travellers, where King John signed the Magna Charta in 1215. 
So where within my garden plat,

I sow the choicest seed,

Amid my favorite shrubs I placed

The plant from Runnimede.

And know not why it may not draw

Sweet nutriment, the same

As when within that noble clime

From whence our fathers came.

Here's liberty enough for all,

If they but use it well,

And Magna Charta's spirit lives

In even the lowliest cell,

And the simplest daisy may unfold

From scorn and danger freed,

So make yourself at home, my friend,

My flower from Runnimede. 
THE TRAVELLED FLOWER.

THE TRAVELLED FLOWER.

A DAISY, which once grew on the banks of the Thames, in England, had been transplanted and brought to this country. It bore the voyage well, and flourished in the garden where it was placed.

A Cowslip, its nearest neighbor, was very kind, and if it ever looked sad, like a stranger, cheered it, and spoke words of comfort. It asked much of its adventures on the ocean, and of its native land. So it told its friend the Cowslip, whatever it desired to know.

It described the ship sailing quietly over the great waters, and its pleasant intercourse with a pansy that bore it company. "We stood side by side on a shelf, in the room of the person, with whom we emigrated.

"The Pansy was blessed with a large family 
98

\section{VOICE OF FLOWERS.}

of fine children, and I had two promising infants when I began the voyage. But they pined for the free air, and the fresh dews of the valley where they were born.

"I was ever watching and nursing them. One night, we were alarmed by great confusion and noise, and a chill that struck us to the heart. We heard a cry of "icebergs," and peeping through the window of our state room, saw monstrous masses of cold glittering ice floating around us.

"Then I heard the Pansy whispering to her little ones, not to be afraid to die. But I trembled with terror. That very night my youngest darling died. And had it not been for the care of my other drooping babe, I think I should have died too.

"The next day, they said we were out of danger, and the keen wintry cold passed away. And though we arrived safely, and I am happy in my new home, I never can bear to think of the voyage where my poor little one perished."

The kind neighbor could not help shivering with sympathy at the tale of sorrow. "I have heard people who walk in the garden, call you the Daisy of Runnimede. What can they 
THE TRAVELLED FLOWER.

mean by such a hard name ?" asked the Cowslip.

"It is a delightful green vale in England, where, in old times, a king signed a paper, which gave the people freedom. For that reason it is visited as a sort of sacred place.

"My birth there, was all that gave me value in the eyes of my owner, and procured me the privilege of travelling to see distant lands." Many things the Daisy related, so that the Cowslip, thus daily instructed, knew almost as much of foreign countries as if it had been there.

A Dandelion lived near, but did not incline to listen to these adventures. Indeed, she ridiculed the way in which her neighbors spent so much of their time, and said for her part, she had something else to do.

She thanked her stars she was not a blue, -no! not she! nor a pedant neither. The vanity of those travelled people was extremely ridiculous, always talking about what they had seen. She laughed loudly at the Cowslip, caling her an antiquarian, and said she wondered what good came from being such a deal wiser than other people. 
A Sage-plant, who had cast off his blossoms, and gone to seed, hearl her flippancy of speech and reproved her. He said, "knowlege is good; it teaches men how to be useful to each other, and keeps women from too much gadding abroad.

"By knowledge, my own salulrious properties have been discovered, so that I am not cut down like a common weed. Right knowledge teaches both men and flowers not to be slanderous, for it gives them higher and better subjects of thought."

So the Dandelion was silent before the Sage and ceased to laugh at those who were wiser than berself. For she had already perceived that they had some kind of secret happiness, and took comfort when other flowers were out of spirits, on stormy days, and when no butterflies visited them. 
SPRRNG IR C'SEOMS, ETC.

\section{SPRING BLOSSOMS TO THE M OURNER.}

Tноu bringest violets in thy hand, Sweet Spring. Thy gifts how vain To soothe us for those fair, blue eyes, That ope no more again.

Thou bringest music of the birds, As if such strain could pay

For their melodious speech, who sank From our lone bowers away.

Thou showerest breathing roses round, To blush on beauty's breast ;

Give back ! give back those lips of rose, That to our own were prest. 
Thou know'st to burst the tyrant gloom Of Winter's icy urn;

Teach them to break the envious tomb, And to our arms return.

Thou canst not! To our grieving souls Thy boasted spell is o'er;

From all thy gifts to those we turn, Whom thou canst ne'er restore.

To those o'er whom thy quicken'd turf, With earliest snow-drops grows, Yet fails to wake their wonted smile, Or move their deep repose.

Yes; from thy charms to Him we turn, Who laid our treasures low, And, with a Father's love, ordains Our discipline of woe :

We losk to that unsullied clime, Where storm shall never sweep; Nor fickle Spring the heart beguile, Nor drooping mourner weep. 
THE HARE-BELL.

\section{THE HARE-BELL;}

A DEDICATION FOR AN ANNUAL, WITH THAT TITLE.

YE have seen me oft, 'mid the summer day, In my woodland home, with the breeze at play; Catching the dews as they sparkling fell, And folding them close in each floral bell; And teaching my buds, with a joyous ray, To lift their blue eyes to the King of Day.

But now, when the last leaf of Autumn is shed, Ye thought, no doubt, I was sere and dead :

No, no! I have baffled the Spoiler's sting, Affection's token to you to bring.

I have dared the wrath of the frosty sky, To gather you blossoms that cannot die.

Will ye welcome me in from my toil and care, For the blessings I breathe, and the sweets I bear?

If ye give me shelter this wintry hour, If ye make me a guest at the hearth and bower, You will never regret, I am fain to say, The Hare-Bell's visit, this Christmas-day. 


\section{EVEN ING FLOWERS.}

WHEN shuts the rose at even tide, The lily folds its bell, And every bud on vale or wild, Dream in their hermit cell.

Then, neath still twilight, dim and grey, Or where the taper stands,

Or meekly by the fireside ray, The flower of heart expands.

The influence of this favoring hour The watchful lover knows, And marks its soft mimosa leaves Their modest charms disclose.

The husband by its fragrance cheer'd, Unlocks the cares of day, Which, neath the warm, confiding smile, Like shadows, fleet away. 
The fond exulting parent culls

Its blossoms, rich and red,

And twines a garland bright with hope

For each young slumberer's head.

While they who best its root protect,

With thrilling breast shall prove,

How the sweet charities of home

Fit for a heaven of love.

But when this heart-flower droops its head,

And wearied mortals ask

The deep repose that nightly fits

For morn's returning task,

Up springs another by its side,

With calm and lowly eye,

A seraph-planted germ that holds

Communion with the sky :

The flower of soul! Its breath is prayer,

And fresh its balm-drops flow,

To cleanse the ills that stain'd the day,

And heal the wounds of woe.

While gently o'er its closing sigh,

With blessed vision bends

That angel-guarded sleep, which God

To his beloved sends. 


\section{THE GARDEN AND THE}

\section{R A I N .}

ONE summer there had been a long drought, made more painful by intense heat. Young trees drooped; many plants withered away ; and the newly-mown grass crisped under the feet as though it would never spring again.

The master of a garden went forth at the sunset to water it. He was grieved to see how his nurslings suffered. The slight branches of the fruit-bearing trees were brittle, and broke at the touch; and the juiceless berries, shrinking away, tried to hide behind their yellow leaves.

The cisterns had become low, and the shallow brooklets were dry; yet he gave water to all his plants, as plentifully as he could. Still they looked languidly at him, as if asking"Can you do nothing more to help us ?" Some were perishing at the root, for the earth to which they clung was like powder and dust. 


\section{THE GARDEN AND THE RAIN.}

That night he awoke, and heard the blessed rain falling; at first, gently, and then with power. He thanked the Merciful Giver, and remembered the words, "Can all the vanities of the heathen give rain? or can the heavens without Him, give showers?"

In the morning, when the rain had ceased, he walked in his garden. He rejoiced, with his plants and flowers, in the great goodness of God. Their long season of sorrow had made them dearer to him, as the parent loveth the child who has been sick with a more tender love.

But now their time of suffering was past. The grape-vine, having put on beauty for ashes, wore at every point of its broad leaves a pearl: and the honey-suckle, which was thought to have been dying, was heard teaching its young tendrils where to twine.

The willow, whose long wands had turned yellow, from disease, was weeping for joy. Every infant blossom tried to tell of its new happiness. Birds carolled from the nest, and breathed into their silent praise a living soul.

As he passed among the shrubbery, every reaching bough shed on him a few chrystal drops. They seemed to have saved for the 
master a portion of what they best loved. The statelier plants secreted a little moisture to bestow upon the lowly. They had themselves known want, and it seemed to have made them more pitiful.

He took in his hand the long leaves of a lily, which, the day before, was ready to perish, and it poured him one fragrant drop from its cup of snow. And the rose-bud gave him, from its heart, a chrystal gem that it had treasured there, saying, "Here! here ! take this, thou who didst minister unto me in my need, and when I was thirsty, give me drink."

A forget-me-not, which he had removed a few days before, from the dominion of a thorny raspberry, had reserved a little rain, to bestow upon the grass-cups at her side. As he bent over her, she seemed to raise her blue eyes and whisper, "I was in prison, and ye came unto me ; sick, and ye visited me."

Then the master of the garden said, "Oh! thankless human heart, that daily takest thy water, and thy bread, yet yieldest scarcely one smile unto God-perchance art angry because of some smitten gourd, or some rose-leaf doubled upon thy pillow-come forth, after the shower of summer, and be abased. 


\section{THE GARDEN AND THE RAIN. 109}

"See, every leaf and bud share the pure essence of their life with all around. The sigh of the lightest breeze wakes their charity. They refuse not, as long as any thing remains to give. Hast thou no surplus drops of Heaven's bounty? Hoard them not from thy brother, the frail partaker of the same clay; but, instructed by the branches of thine own planting, become wise unto eternal life." 


\section{VOICE OF FLOWERS.}

\section{CHANGES DURING SICKNESS.}

I Bow'D me down amid the race of life, And let the fever-spirit have its will.

With wrench and screw the tissued nerves it tried,

And held from sleep the strained and burning eye,

So that the soft-voic'd watcher's toil was vain. Two weeks passed by, and then His healing love,

Who knows the weakness of this mortal frame Which He hath fashioned, bade me take my place

Again among the living.

Strange and new

Seemed every wonted object. All around Change had been busy. Boldly up had sprung, Even to the eaves, the rich Convolvolus, So long with patience water'd, even and morn. Its clustering floral bells, profoundly blue, 
Or crimson, fleck'd with white, thro' the broad leaves,

Were redolent of beauty. So, methought I'd close my books, and study with the flowers, Where sang the bee; and where, for aught I knew,

Might winged angels hover.

\section{Closely hid}

In a dense grape-vine, was a cunning nest,

Which oftimes I had visited, to strew

Crumbs for the brooding mother. On that morn

When fell disease stalk'd near me with his chain,

Intent to smite me, tho' I knew it not,

I had withdrawn those curtaining leaves, and met

Her clear, bright eye.

Now, all were fled and gone!

Yes, those small eggs with gladness and with song

Had travell'd forth to swell the tide of love That bathes Creation in its boundless sea.

Oh! ever-watchful goodness, that doth work Whether we sleep, or, 'neath the weight of pain,

Bow down in dreamy reverie; while time, 


\section{VOICE OF FLOWERS.}

Unnoted, glideth onwards, nest and flower Confess thee. Shall the thoughtless human heart,

So much indebted, e'er thy praise forget, Whether beneath the sunshine or the cloud, It takes its lesson from thy page divine? 
TO THE MISLETOE, ETC.

TO THE MISLETOE A T THE TOMB OF WASHINGTON.

DARK plant of Superstition's shade,

Why lift'st thou here the cheerless eye, Where reeks no Druid's purple blade, To stain the Christian's hallow'd shade, Or dim fair Freedom's sky?

Sacred to orgies blind and base,

Where human blood was sternly spilt, How dar'st thou seek this holy place? Rude parasite! whose foul embrace

Hast wreath'd the murderer's hilt.

Where ancient Mona's foliage wept,

Or drear Stonehenge was wrapp'd in gloom, Thy earthless root had fitter crept, Thy mystic garland better slept, Than near a Christian tomb. 
What though in Maro's * fabled lore,

To Troy's bold chief thine aid was lent, Who dauntless trod the infernal shore, Where sad and frowning shades of yore Their date of anguish spent,

Yet we, to Pluto's dreary coast,

Passport from such as thee, disdain; We seek our hero 'mid the host, Where wails no grim and guilty ghost, On Heaven's unclouded plain.

Lo ! watchful o'er his honor'd clay,

A nation sheds the filial tear; And pilgrim's kneel, and patriots pray, And plants of glory drink the day,Why dost thou linger here?

In war the laurel wove his crest, The olive deck'd his sylvan dome, The mournful cypress marks his rest, Dark Misletoe! the Druid's guest, Hence! seek some fitter home.

* The Viscum Albun of Linnaus, or sacred misletoe of the Druids, is the plant which was the passport of Aneas in his descent to the Infernal Regions. See Fneid, Book 6th. 
THE MINISTRY OF FLOWERS.

THE MINISTRY OF FLOWERS.

FLOWERS! Flowers! the poetry of earth, Impulsive, pure, and wild;

With what a strange delight they fill

The wandering, mirthful child ;

It clasps their leaflets close a while,

Then strews them wide around;

For life hath any a joy to spare

Along its opening bound.

The maiden twines them in her hair,

And, 'mid that shining braid,

How fair the violet's eye of blue, And the faint rose-bud's shade,

Upon her polish'd neck they blush.

In her soft hand they shine,

And better crown those peerless charms Than all Golconda's mine. 
Above the floating bridal veil

The white Camella rears

Its innocent and tranquil eye,

To calm young beauty's fears, And when her hoary age recalls

The memories of that hour,

Blent with the heaven-recorded vow

Will gleam that stainless flower.

The matron fills her chrystal vase With gems that Summer lends, Or groups them round the festal board To greet her welcome friends, Her husband's eye is on the skill With which she decks his bower, And dearer is his praise to her Than earth's most precious flower.

Frail gifts we call them, prone to fade Ere the brief spring is o'er,

Though down the smitten strong man falls,

Returning never more.

Time wears away the arch of rock,

And rends the ancient throne,

Yet back they come, unchang'd, as when

On Eden's breast they shone. 
THE MINISTRY OF FLOWERS.

How passing beautiful they are,

On youth's unclouded plain,

And yet we scarcely know their worth

Till life is on its wane,

Then grows their love a deeper thing,

As our lone path-way tends

Down 'mid the withering plants of hope,

And graves of buried friends.

Like ready comforters, they bend,

If sorrow pales the cheek, And to the sad, desponding heart

An angel's message speak, While, to the listening mourner's ear,

They fondly seem to say

The words of those departed ones,

Who sleep in mouldering clay.

We nurse them in our casement warm,

When Winter rules the year,

And see them raise their graceful form,

The darkest day to cheer; Within our coffin-lid they glow,

When death hath had his will,

And o'er our pillow in the dust

They bend and bloss.om still. 
118

VOICE OF FLOWERS.

Yes, o'er our cradle-bed they creep, With rich and sweet perfume, Around the marriage altar twine, And cheer the darksome tomb; They whisper to the faithful dead With their fresh, vernal breath, That such his rising hour shall be, Through Him, who conquer'd death.

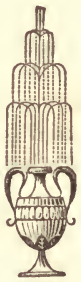


THE WINTER BOUQUET.

THE WINTER BOUQUET.

FLowers! fresh flowers, with your fragrance free,

Have ye come in your queenly robes to me? $M e$ have ye sought from your far retreat, With your greeting lips, and your dewy feet; And the upward glance of your radiant eye, Like angel guests from a purer sky?

But where did ye hide when the frost drew near,

And your many sisters were blanched with fear?

Where did ye hide? with a blush as bright As ye wore amid Eden's vales of light, Ere the wile of the Tempter its bliss had shamed,

Or the terrible sword o'er its gate-way flam'd. 


\section{VOICE OF FLOWERS.}

Flowers, sweet flowers, with your words of cheer,

Thanks to the friend who hath sent you here. For this, may her blossoms of varied dye Be the fairest and first 'neath a vernal sky; And she be led, by their whispered lore, To the love of that land where they fade no more.

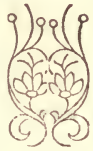


FAREWELL TO THE FLOWERS, 121

FAREWELL TO THE FLOWERS.

Go to your peaceful rest,

Friends of a brighter hour,

Jewels on youthful beauty's breast,

Lights of the hall and bower.

Well have ye done your part,

Fair children of the sky,

We'll keep your memory in our heart,

When low in dust ye lie.

Your gladness in our joy,

Your smile beside our way,

Your gentle service round the bed

Of sickness and decay,

Your rainbow on the cloud,

Your sympathy in pain;

We'll keep the memory of your deeds

Until we meet again. 
Rest, from the blush of love; Rest, from the blight of care, From the sweet nursing of your buds, And from the nipping air ;

Rest, from the fever-thirst

Of summer's noontide heat, From coiling worm, and rifling hand, That vex'd your lone retreat.

If e'er ye thrilled with pride, When the admirer knelt, Or on the lowly look'd with scorn, Which man for man hath felt, If through your bosoms pure Hath aught like evil flow'd, (Since folly may with angels dwell,)

Rest from that painful load.

But not with grief or fear,

Bow down the drooping head; See ! in the chamber of your birth

Your dying couch is spread; Go! strong in faith, ye flowers ;

Strong in your guileless trust, With the returning birds, to rise Above imprisoning dust. 
FAREWELL TO THE FLOWERS, 123

Hear we a whisper low, From withering leaf and bell? "Our life hath been a dream of love, In garden, or in dell; Yet wintry sleep we hail, And, till the trump shall swell, To wake us on the vernal morm, Sweet friends, a sweet farewell!"

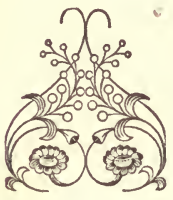




\section{GLOSSARY}

\section{OF FLOWERS MENTIONED IN THIS VOLUME.}

Acacra, . - . . Concealed love. Almond, . . . . Hope.

Amaranth, . . . Immortality.

Amaryllis, . . . Beautiful, but timid.

Anemone, . . . Anticipation.

Aspen, ..... Tenderness.

Aster, . . . . . Love of variety.

Bluebell, . . . Health.

Box, . . . . . . Constancy.

Buttercup, . . . Riches.

Cactus Speciosissimus, . Perfect beauty.

Calla, . . . . . . Magnificent beauty.

Camella, . . . Unpretending excellence.

Carnation, . . . Pride and beauty.

Cereus, . . Long life.

Chamomile, . . . . Energy in adversity.

Chrysanthemum, . . . A heart left to desolation.

Clematis,. . . . . Mental beauty.

Columbine, .. . Desertion.

Convolvolus, . . . Worth sustained by affec-

Cowslip, . . . Winning Grace.

Coxcomb, . . Fashion.

Crown Imperial, . . . Pride of riches.

Cypress, . . . . Despair. 


\section{GLOSSARY.}

Daffodil, . . . . Uncertainty.

Dahlia, . . . . Elegance and beauty.

Daisy, . . . . Beauty and innocence.

Daisy, Mountain, . . Meek loveliness.

Dandelion, . . . . Coquetry.

Eglantine, . . . I wound to heal.

Fleur de lis, . . . Aristocracy.

Flowering Bean, . . Industry.

Forget-me-not, . . . True love.

Fox-Glove, . . . Insincerity.

Geranium, . . . Gentility.

Geranium, Rose, . . Preference.

Gladiolis, . . . Martial taste.

Grape,. . . . . Mirth.

Hackmetrck, . . . Single blessedness.

Hare-Bell, . . . . Grief.

Hawthorn, . . . Hope.

Heliotrope, . . . Devotion.

Holly, . . . Domestic happiness.

Hollyhock, . . . Ambition.

Honeysuckle, . . . Fidelity.

Honeysuckle, Trumpet, . Inconstancy.

Hyacinth, . . . Friendship in adversity

Hydrangia,. . . . Heartlessness.

Ice-Plant, . . . . An old beru.

Iris, . . . . . My compliments.

Ivy, . . . . Wedded love.

Jessamine, . . . Amiability.

Jonquil, . . . . I desire a return of affection.

Lady's-Slipper,. . . . Capricious beauty. Larkspur, . . . Haughtiness. 
Laurel, . . . . I change but in dying.

Lilac, Persian, . . An accomplished traveller.

Lilac, Purple, . . . . Fastidiousness.

Lilac, White, . . . Youthful innocence.

Lily, White, . . . Purity and benuty.

Lily of the Valley, - Delicate simplicity.

Lobelia, . . . . Malevolence.

London-Pride, . . Frivolity.

Lupine, . . . . Dejection.

Maple, . . . . Reserve.

Marigold, . . . Jealousy.

Mignionette, . . . Your virtues surpass your

Mimosa, . . . . Sensitiveness.

Misletoe, . . . Superstition.

Monk's-Hood, . . . Deceit.

Mourning Widow, . . Berenvement.

Myrtle, . . . . Love in absence.

Narcissus, . . . . Self-love.

Nightshade, . . . Dark thoughts.

Oleander, . . . Beware!

Olive, . . . . Peace.

Pansy, . . . . Pleasant thoughts.

Pen, Everlasting, . . Wilt thou go with me?

Pea, Sweet, . . . Departure.

Pink, . . . . . Woman's love.

Piony, . . . . Anger.

Polyanthus, . . . . Confidence.

Poppy, Red, . . . Evanescent pleasure.

Poppy, White, . . . Consolation.

Primrose, . . . Modest worth.

Ragged Lady, . . . . Bad housekeeping.

Rhododendron, . . Majesty.

Rose, . . . . . Beauty and prosperity. 


\section{GLOSSARY.}

Rose, Cinnamon, . . . Maternal care. Rose, Damask, . . . . Bashful love. Rose, Thornless, . . . Ingratitude. Rose, Multiflora, . . Grace. Rose, Moss, . . . Superior merit. Rose, Wild,. . . . . Lightness. Rose-bud, Moss, . . Confession. Rose-bud, White,. . . Too young to love.

Sage, . . . . . Domestic virtues. Snowball, . . . Thoughts of Heaven. Soldier in Green, . . . Undying hope. Spruce, . . . . Integrity. Sunflower, . . . Lofty thoughts. Sweet-Briar, . . . Simplicity. Sweet-William, . . A smile.

Thistle, . . . . Misanthropy. Tulip, . . . A declaration of love.

Venus's Fly-Trap, . Artifice.

Verbens, . . . Sensibility. Violet, . . . Modesty.

Water-Lily, . . . Purity of heart. Wax-Berry, . . . . Confiding trust. Willow, Weeping, . . Forsaken love. Woodbine, . . . Fraternal love.

THE END. 







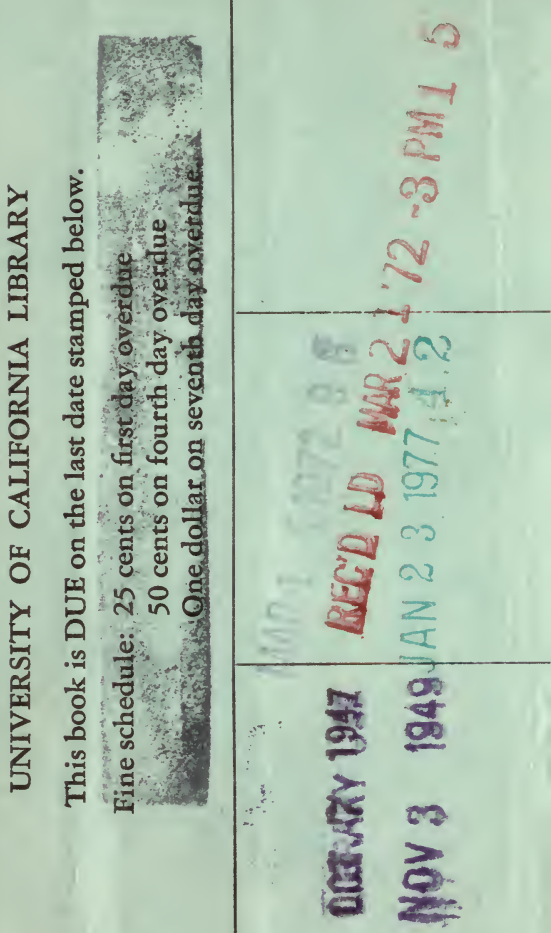



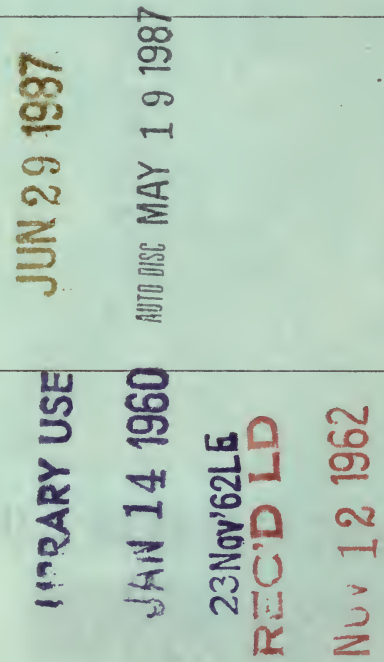

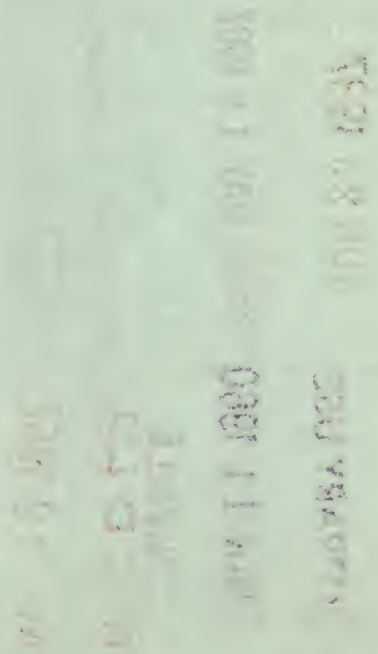


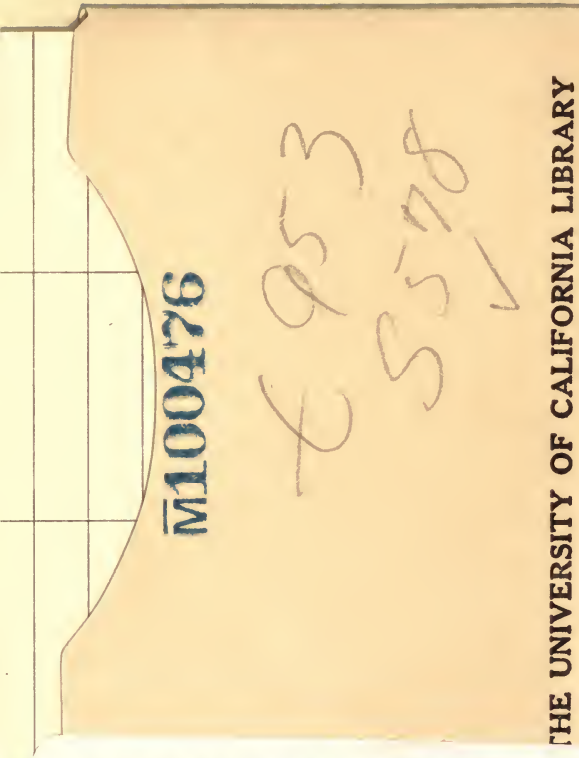

\section{U.C. BERKELEY LIBRARIES}

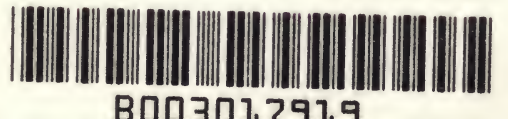


